\title{
Youth Rural-Urban
} Migration in Bungoma, Kenya: Implications for the Agricultural Workforce

Elizabeth Eckert, Eleanor Turner, and

Jo Anne Yeager Sallah 
This publication is part of the RTI Press Research Report series. Occasional Papers are scholarly essays on policy, methods, or other topics relevant to RTI areas of research or technical focus.

RTI International

3040 East Cornwallis Road PO Box 12194

Research Triangle Park, NC 27709-2194 USA

Tel: +1.919 .541 .6000$

E-mail: rtipress@rti.org

Website: www.rti.org

\section{RTI Press publication OP-0062-1908}

RTI International is an independent, nonprofit research organization dedicated to improving the human condition. The RTI Press mission is to disseminate information about RTI research, analytic tools, and technical expertise to a national and international audience. RTI Press publications are peer-reviewed by at least two independent substantive experts and one or more Press editors.

\section{Suggested Citation}

Eckert, E., Turner, E., and Yeager Sallah, J. A. (2019). Youth Rural-Urban Migration in Bungoma, Kenya: Implications for the Agricultural Workforce. RTI Press Publication No. OP-0062-1908. Research Triangle Park, NC: RTI Press. https://doi.org/10.3768/ rtipress.2019.op.0062.1908

O2019 RTI International. RTI International is a registered trademark and a trade name of Research Triangle Institute. The RTI logo is a registered trademark of Research Triangle Institute.

\section{(c) (i) () $\ominus$}

This work is distributed under the terms of a Creative Commons AttributionNonCommercial-NoDerivatives 4.0 license (CC BY-NC-ND), a copy of which is available at https://creativecommons.org/licenses/by-nc-nd/4.0/legalcode 


\section{Contents}

About the Authors

Acknowledgments

Abstract

Introduction

Literature Review

Methodology

Qualitative Methodology

Quantitative Methodology

\section{Bungoma Respondent Profile}

3

\section{Analysis}

Migration Experiences of Rural Youth

Push and Pull Factors for Youth Migration Out of Rural Areas

Planning for Youth Migration

Perceptions of Post-Migration Challenges

Employment Profile

Support to Family and Network in Villages of Origin

Interest in Returning to the Village

Discussion and Conclusions

Suggestions for Further Research

Returning to Home Villages

Household and Community Resilience

Gender Considerations

Countering Violent Extremism

References

\section{About the Authors}

Elizabeth Eckert, MA, Senior Food Security and Agriculture Specialist, RTI International

Eleanor Turner, MSc, Food Security and Agriculture Specialist, RTI International

Jo Anne Yeager Sallah, MSc, Senior Food Security and Agriculture Specialist, RTI International

RTI Press Associate Editor Eric M. Johnson 


\section{Acknowledgments}

The authors thank RTI contributors Charles Lau, Clark Letterman, Leenisha Marks, and Stirling Cummings for their efforts designing and implementing this study, and Anna Vasylytsya for her thorough data cleaning and analysis. We thank the team at Research Solutions Africa (now Dalberg), including Teresa Dacha and Peter Otienoh, for conducting the survey, focus groups, and interviews. Most importantly, we are grateful to those Kenyan youth who took the time to thoughtfully participate in our research.

\section{Abstract}

This study provides insights into a specific, hard-to-reach youth subpopulationthose born in agricultural areas in Western Kenya who migrate to large towns and cities - that is often missed by research and development activities. Using a mixed-methods approach, we find high variability in movement of youth between rural villages, towns, and large urban areas. Top reasons for youth migration align with existing literature, including pursuit of job opportunities and education. For youth from villages where crop farming is the primary economic activity for young adults, 77 percent responded that they are very interested in that work, in contrast to the common notion that youth are disinterested in agriculture. We also find many youth interested in settling permanently in their villages in the future. This research confirms that youth migration is dynamic, requiring that policymakers and development practitioners employ methods of engaging youth that recognize the diversity of profiles and mobility of this set of individuals. 


\section{Introduction}

The challenge of providing meaningful employment for young adults in Africa has become an important focus in the development community. Unemployment rates among youth everywhere are higher than among adults. In Kenya, nearly 75 percent of the population is under age 30 , and 26 percent of youth ages 15-24 are unemployed (United Nations Development Programme, 2018). Kenyan youth appear to be increasingly rejecting rural agricultural livelihoods (Afande et al., 2015; Republic of Kenya Ministry of Agriculture, Livestock and Fisheries, 2017) and migrating to cities, where a lack of rural employment opportunities resurfaces as urban unemployment and underemployment.

In parallel, increasing migration has raised concerns about rural youth abandoning agriculture, and the implications for agricultural production and food security. The food and agriculture sector is still the largest employer of young people (Yeboah, 2018), but increasing rural-urban migration rates (UN Habitat, 2018) and concerns that youth prefer nonagricultural employment have prompted the development community to explore ways to harness the potential of youth to revitalize rural agricultural economies.

To inform such solutions, we explore the migration patterns of youth from predominantly agricultural areas in Western Kenya (specifically Bungoma County), the profile of those migrants who plan to return to their villages, and implications for the agricultural workforce. Using data from a survey of approximately 2,400 rural-urban youth migrants conducted in 2017 from two rural counties (Bungoma and Garissa), we uncover behaviors and aspirations of this important yet difficult-to-study cohort.

\section{Literature Review}

Many studies have attempted to elucidate youths' perspectives on agriculture and the factors that drive migration, including in Western Kenya. Youth state that educational and employment opportunities drive their decision to migrate to urban areas (Miguel \& Hamory, 2009; Kristensen \& Birch-Thomsen, 2013).
In Western Kenya, youth migrating for employment opportunities report doing so because the education they have received is better aligned with urban jobs (Oucho, Oucho, \& Ochieng, 2014) and young women cite marriage as a driver of migration to urban areas (Miguel \& Hamory, 2009). Other factors cited by Kenyan youth as reasons to move to urban areas include poor rural living conditions, cultural practices, and access to health and other services in urban areas (Miguel \& Hamory, 2009; Oucho et al., 2014).

Many studies have sought to understand why youth are not interested in agriculture, though most use qualitative methods and/or small sample sizes. Overwhelmingly, this body of research points to limited access to land as a barrier to agricultural livelihoods in Kenya (Njenga et al., 2012; Oucho et al., 2014; Mwangi et al., 2016; Noorani, 2015; Osti et al., 2015). Similarly, lack of access to finance is frequently cited as a deterrent (Njenga et al. 2012; Mwangi et al., 2016; Noorani, 2015; Osti et al., 2015). Some studies note that school curricula are not aligned with agriculture (Njenga et al., 2012; Osti et al., 2015). Preferences and perceptions are also cited as deterrents to agricultural livelihoods, including perceived low productivity, returns, and earning potential of farming; seasonality and uncertainty of income; intensity of manual labor; desire for a more professional or respectable career; and general lack of interest (Oucho et al., 2014; Njenga et al., 2012; Osti et al., 2015; Leavy \& Hossain 2014; Mwangi et al., 2016; Kristensen \& Birch-Thomsen, 2013).

These studies leave gaps in our understanding of youth out-migration from rural areas. Many of the studies listed previously on youths' perspectives on agriculture draw on interviews with village youth who have not migrated. Few of the studies employ rigorous methodologies (Miguel \& Hamory, 2009 , is a notable exception), and few target large sample sizes of youth who have already migratedlikely because this population is difficult to find. Policymakers and practitioners are challenged to support youth migrants in preparing for and finding productive employment, in part because of a limited understanding of migration experiences. 


\section{Methodology}

We used a mixed methods approach, including qualitative focus groups and key informant interviews, and an in-person survey.

\section{Qualitative Methodology}

To elicit insights about the migration experience, we conducted 12 qualitative focus group discussions with youth migrants (see Table 1).

\section{Table 1. Breakdown of focus group discussions}

\begin{tabular}{llc}
$\begin{array}{l}\text { Location of focus } \\
\text { group discussion }\end{array}$ & $\begin{array}{l}\text { Origin of } \\
\text { participants }\end{array}$ & $\begin{array}{c}\text { Number of focus } \\
\text { group discussions } \\
\text { held }\end{array}$ \\
\hline Nairobi & $\begin{array}{l}\text { Born in Bungoma } \\
\text { County villages }\end{array}$ & 3 \\
\hline Nairobi & $\begin{array}{l}\text { Born in Garissa } \\
\text { County villages }\end{array}$ & 3 \\
\hline Bungoma Town & $\begin{array}{l}\text { Born in Bungoma } \\
\text { County villages }\end{array}$ & 3 \\
\hline Garissa Town & $\begin{array}{l}\text { Born in Garissa } \\
\text { County villages }\end{array}$ \\
\hline
\end{tabular}

In addition, we conducted 24 key informant interviews with stakeholders within the youth migrant communities. We conducted 12 interviews in Nairobi, 6 each with migrants from Garissa and Bungoma, plus 6 interviews in Bungoma Town and 6 in Garissa Town. Key informants were selected based on their interactions with and knowledge about the migrant populations of interest and included employers, educators, and community leaders. Focus group discussions and key informant interviews were conducted in Kiswahili and Luhya for Bungoma youth migrants and in Kiswahili and Somali for Garissa youth migrants. We captured data by audio recording and notetaking.

For the analysis, we first categorized focus group discussion content across common themes emerging from the discussions. We then supplemented comments with analysis of key informant interviews. We developed a separate qualitative methods report outlining the key findings (currently pending review at a journal), and we used that report to inform our analysis of the survey data.

\section{Quantitative Methodology}

For the quantitative survey, RTI's data collection partner Research Solutions Africa (RSA) surveyed 2,417 Kenyans between the ages of 18 and 35 born in rural areas in Bungoma and Garissa counties who had since migrated to major towns or Nairobi. We used respondent-driven sampling (RDS), a method of chain referral sampling created to study hard-to-reach populations. RDS functions like a snowball sample, with several important modifications that minimize the biases of snowball sampling (Heckathorn, 2002). ${ }^{1}$

RSA began data collection by recruiting 20 "seed" respondents, selected from focus group discussion participants. After participating in the survey, respondents were asked to recruit up to three people to participate in the study. Respondents received 50 shillings ( $\sim$ US $\$ 0.50$ ) in phone airtime for completing the survey, 75 shillings each for the first two successful referrals, and 100 shillings for the third. Respondents recruited other people from their networks in successive waves of data collection. Referrals continued through as many waves as were necessary to complete the target number of interviews for each network. Our network analysis, which appears in our unpublished methods report, shows the patterns of homophily, that is, the tendency to recruit people with similar demographic characteristics to oneself. Among "Bungoma to Nairobi" migrants, for example, educated people were unlikely to recruit uneducated people (and vice versa).

RSA then conducted face-to-face interviews in the location and language (English, Kiswahili, Luhya, Bukusu, and Somali) chosen by the respondent. RTI cleaned and analyzed the collected survey data in Stata, using summary statistics and cross-tabulations to generate the findings presented in the following sections.

Although the potential biases of snowball sampling are minimized by RDS, the methodology still has limitations. For example, with RDS it is possible to

\footnotetext{
1 Biases associated with chain referral sampling are derived from the choice of the initial sample, volunteerism, differential recruitment (some groups recruiting more referrals than others), and homophily. Respondent-driven sampling imposes quotas to minimize initial sample bias and offers incentives to minimize volunteerism bias (Heckathorn, 2002).
} 
oversample from discrete networks or clusters of individuals with similar experiences, such as from a similar educational program. Survey results from within a small cluster may indicate a high prevalence of a certain response, but in the final analysis, the result may not be representative of the general population. We tried to minimize this limitation by using a large number of seeds (10 from each county) and limiting referrals to three per individual.

\section{Bungoma Respondent Profile}

For the purposes of this paper, we focus on only those respondents who were born in rural areas of Bungoma County, ${ }^{2}$ a predominantly agricultural region of Western Kenya. Bungoma County has a population of 1.6 million inhabitants, 53 percent of whom live below the poverty line (Commission on Revenue Allocation [Kenya], 2011). The county enjoys high rainfall, which fosters agricultural productivity, particularly in the maize and sugarcane sectors. Agriculture is estimated to account for up to 70 percent of jobs in Bungoma County, and youth unemployment is estimated at 60 percent (County Government of Bungoma, 2013).

The topic of this paper is to explore youth migration in relation to agricultural livelihoods; a separate paper could explore the differences between Bungoma and Garissa counties. We focus on Bungoma County for two main reasons. First, because of the agricultural nature of the county, it provided an opportunity to examine preferences about a specific livelihoods profile that is more reflective of the literature concerned with the exodus of youth from agriculture. Garissa is a pastoral county with less agricultural productive potential. Second, upon our initial review of the data across the two counties, it became clear that the migration experience is inherently different between them. Most notably, in the Garissa data, we noticed a high frequency of enrollment in postsecondary education programs.

Our sample consists of youth born in villages in Bungoma County who were living in Nairobi or

\footnotetext{
2 Data from both Garissa and Bungoma will be included in a forthcoming paper on the use of RDS methodology for this study. Additional papers or outputs may include a focus on Garissa youth.
}

Bungoma Town at the time of the survey. Bungoma Town is the county capital and second largest town in the county, with a population of approximately 55,000 . Because our sampling process was based on the location of the respondents at the time of the survey, the profiles presented should not be interpreted as representative of all youth migrants born in Bungoma County.

Table 2 provides a summary of the demographic profile of these respondents. As we anticipated, most survey respondents come from rural households whose primary economic activity is agriculture- or livestock-related. Although we aimed for an even distribution of male and female respondents through the sampling process, the survey ultimately included 67 percent men. This could be attributed to more men being a part of our population of interest. Additionally, after the initial pilot, we determined that for females who had migrated exclusively to follow their husbands, many of our research questions were not relevant, so we included filter questions in our final survey to exclude that specific profile.

Table 2. Bungoma County in-person survey respondent profile

\begin{tabular}{lc}
\hline Total Bungoma County respondents (n) & 1,350 \\
\hline Currently living in Nairobi (\% of total) & 48.0 \\
\hline Currently living in Bungoma Town (\% of total) & 51.9 \\
\hline Mean age (at time of survey) & 25.9 \\
\hline Male respondents (\% of total) & 67.0 \\
\hline Completed secondary education or higher (\% of total) & 65.0 \\
\hline Married at time of survey (\% of total) & 50.6 \\
\hline Household owns land (in origin village, \% of total) & 92.9 \\
\hline $\begin{array}{l}\text { Primary household economic activity is crop farming } \\
\text { and/or livestock keeping (in origin village, \% of total) }\end{array}$ & 91.9 \\
\hline
\end{tabular}

No accurate statistics exist for the domestic migration rate of youth in Bungoma, as these individuals are difficult to track and migration is fluid. A long-term panel study in Busia, a neighboring county, found that 55 percent of adolescents had left the county for a period of at least 4 months, and 28 percent were not currently living in the county 10 years after primary school (Miguel \& Hamory, 2009). The 2009 census estimated that 4 million Kenyans (10 percent 
of the population) had migrated within the country (Government of Kenya, 2009).

\section{Analysis}

\section{Migration Experiences of Rural Youth}

Our survey captured a detailed history of each respondent's migration since age 12 . The mean age of first migration (the age at which they left their home village) is 20 years old and does not differ significantly by gender or education level of respondent. This aligns with most youth completing secondary education and accessing official identification documents (required for migration) at age 18. Among our sample of Bungoma County youth, 32 percent moved directly to Nairobi for their first migration, whereas 26 percent moved to Bungoma Town first (Figure 1 provides a map of Kenya and Bungoma County). Respondents had migrated an average of two times at the time of the survey.

\section{Figure 1. Map of Kenya and Bungoma County}

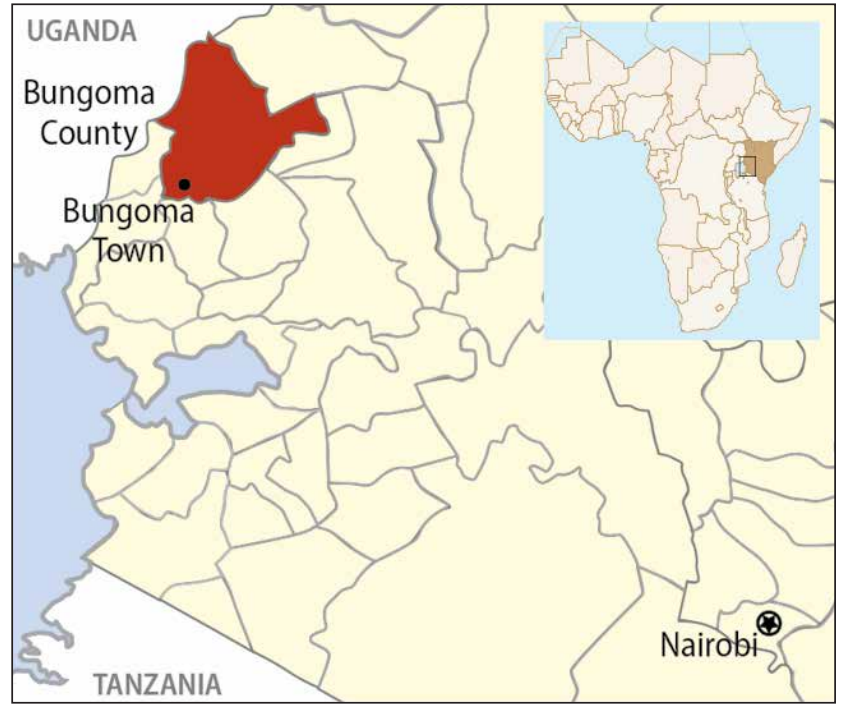

The survey explored the duration of migrants' "stays" in various locations to test the common perception that youth migrants are continually hopping from place to place in search of something better. Most migrants (81 percent) had planned to stay at least a year when they arrived in their current city or town; 51 percent had planned to stay indefinitely. Among those who had planned to stay less than a year, most ended up staying longer. Those who had made more than one migration (55 percent of respondents) stayed in their first destination for an average of 26 months. Note that many of these respondents (30 percent) were enrolled in education at their first destination, which could account for the duration of stay. (Education as a driver for migration is discussed in the next section.)

Among those living in Bungoma Town at the time of the survey, 19 percent had previously lived in Nairobi, indicating that Nairobi is not necessarily the final destination for these migrants. Returning to Bungoma Town, the capital of their home county, could indicate a desire to return closer to home-all respondents were born within approximately a 2-hour driving radius of Bungoma Town. Those individuals spent an average of 21 months in Nairobi before migrating again.

The movement of Bungoma youth is highly variable: of the 1,350 Bungoma youth surveyed, 729 (54 percent) had followed the 10 most common migration pathways, shown in Table 3. The two most common paths were birth village to Nairobi and birth village to Bungoma Town, respectively. ${ }^{3}$ Interestingly, the path village-Bungoma TownNairobi was not among the most common. During focus group discussions, respondents described a phased migration pathway out of the village, spending

\section{Table 3. Migration Path Frequency}

\begin{tabular}{lc} 
Migration path & $\begin{array}{c}\text { Number of } \\
\text { respondents }\end{array}$ \\
Village-Nairobi & 310 \\
\hline Village-Bungoma Town & 297 \\
\hline Village-Nairobi-Bungoma Town & 41 \\
\hline Village-Mombasa-Bungoma Town & 13 \\
\hline Village-Eldoret-Bungoma Town & 12 \\
\hline Village-Kisumu-Nairobi & 12 \\
\hline Village-Busia-Bungoma Town & 11 \\
\hline Village-Kakamega-Bungoma Town & 11 \\
\hline Village-Kisumu-Bungoma Town & 11 \\
\hline Village-Kitale-Bungoma Town & 11 \\
\hline
\end{tabular}

3 This is largely attributable to our sampling strategy, which required that respondents currently reside in Nairobi or Bungoma Town. 
time in smaller towns, then bigger towns (such as Bungoma Town) before moving to Nairobi.

Based on the most popular routes (village-Nairobi and village-Bungoma Town), it appears youth may separate into two categories: those who find what they are looking for in Bungoma Town, and those who target Nairobi from the beginning of their journey. Youth migrating directly to Nairobi may have been influenced by greater educational opportunities in Nairobi, as educational facilities are limited in Bungoma Town. Family connections in either location may influence migrating youths' chosen destination.

Through the focus groups, we learned that many Bungoma migrants move between lakeshore towns frequently in search of the best-paying fishing activities. The focus group discussions also indicated that most youth migrants do not have a clear path plotted out in advance of migration, but rather obtain information and make decisions as they go.

\section{Push and Pull Factors for Youth Migration Out of Rural Areas}

Among male and female migrants in both Nairobi and Bungoma Town, the top reasons for migration were to search for work, a job opportunity, and education. These findings align with prior studies (Miguel \& Hamory, 2009; Kristensen \& BirchThomsen, 2013). No respondents selected civil conflict, lack of land, lack of services, or drought as the primary purpose for their move. Consistent with Muyanga and colleagues (2016), 57 percent of respondents described access to land as "not important" to their decision to migrate from the village. As shown in Figure 2, more important factors included not being able to generate income in their villages, preference for employment opportunities in larger towns or cities, and the desire to send money back to their families.

The survey revealed that push and pull factors for youth were intertwined: the most common combination of factors was the lack of incomegenerating opportunities at home and the pull of potentially better income-generating activities in cities. Focus group discussion findings were consistent with the survey; most respondents cited job and education opportunities as factors driving migration. Sixty-eight percent of respondents said that it was very important to send money back to the family in the home village, indicating that migration is part of a family's overall livelihood portfolio.

The focus group discussions also shed light on some specific push factors: some participants described village members' victimizing unemployed male youths, as well as the simple scarcity of resources within poor families and the inability to support grown children. Focus group discussion participants in Bungoma also noted some hostility toward younger sons in families where there were large numbers of sons.

\section{Figure 2. Importance of factors influencing youth migration}




Although the youth we surveyed reported agriculture to be the primary economic activity in their home villages, wage employment and self-employment were equally common among young people (see Table 4).

\begin{tabular}{|c|c|c|}
\hline Economic activity & $\begin{array}{l}\text { Most common } \\
\text { for young adults } \\
\text { ages } 18-35\end{array}$ & $\begin{array}{l}\text { Primary economic } \\
\text { activity in village }\end{array}$ \\
\hline Crop farming & $12.4 \%$ & $23.3 \%$ \\
\hline $\begin{array}{l}\text { Combination of crop } \\
\text { farming and livestock } \\
\text { keeping }\end{array}$ & $21.1 \%$ & $69.2 \%$ \\
\hline Wage employed & $25.1 \%$ & $1.6 \%$ \\
\hline $\begin{array}{l}\text { Self-employed } \\
\text { (nonagricultural) }\end{array}$ & $20.2 \%$ & $2.4 \%$ \\
\hline Unemployed & $9.6 \%$ & $0.4 \%$ \\
\hline
\end{tabular}

Focus group discussion participants reported difficulty in finding jobs in their villages, noting that agricultural laborers are only needed during planting and harvest time. Examples of wage or selfemployment in the villages included security guards, restaurant workers, M-Pesa (mobile money) shop agents, masons, and auto mechanics. However, focus group participants also noted deterrents to migration, such as a lack of networks in bigger cities and the costs and challenges of migration-specifically, the lack of transport and initial accommodation.

\section{Planning for Youth Migration}

The most important barrier to migration noted in the focus group discussions was the ability to raise funds needed to cover migration costs, such as bus fare, living costs for 1 to 3 months, and identifying initial accommodations. The survey confirmed these results and found no significant differences between male and female respondents. While youth may not plot out their migration journey, they do engage in some preparation activities; many respondents saved money (48 percent), looked for training programs (41 percent), inquired about job opportunities (66 percent), and identified housing (59 percent) in advance of migrating. These questions were not mutually exclusive, so youth could do more than one of the preparation activities. When asked what they consider the most important pre-migration activity and the one that they would recommend to friends interested in migrating, they listed, in order of highest recommended: saving money ( 35 percent), gaining training and skills (24 percent), and researching job opportunities (17 percent).

\section{Perceptions of Post-Migration Challenges}

During the focus group discussions, youth noted several challenges to their perceived success in migration. A common theme was the high cost of living and inadequate housing. They also mentioned difficulty in obtaining jobs (though the survey data indicate that many are finding work) and that the work they had obtained was not necessarily what they had envisioned. The focus group discussions elicited a dissatisfaction with wages and an inability to save income due to everyday expenses. Further, both young women and young men alleged exploitative labor practices. For example, several noted that they did not know the terms of their employment upon starting their jobs.

\section{Employment Profile}

Table 5 provides a summary of Bungoma County migrants' employment experiences upon first migration and at the time of the survey. Among Bungoma males and females able to find a job, 60 and 52 percent (respectively) said that their first job after migrating was not what they had hoped to do. Thirtyfour percent were able to secure a job immediately; another 56 percent found a job within 6 months. Thirty-two percent did not know what they would be paid before accepting their first job, and 50 percent said the salary was lower than they expected. Only 2 percent said their salary was higher than they expected.

Table 5 lists the most common occupations initially after migrating and at the time of the survey. Although there were small changes, we did not find evidence that certain types of occupations were significantly more common among youth who had just migrated. 


\begin{tabular}{|c|c|c|}
\hline Occupation & $\begin{array}{l}\text { First occupation } \\
\text { post-migration (\%) }\end{array}$ & $\begin{array}{c}\text { Current } \\
\text { occupation (\%) }\end{array}$ \\
\hline Watchman & 16.1 & 15.6 \\
\hline Unemployed* & 12.2 & 14.1 \\
\hline Casual worker & 9.5 & 5.6 \\
\hline Other* & 9.2 & 11.6 \\
\hline Student* & 8.4 & 10.7 \\
\hline Masonry & 4.2 & 2.0 \\
\hline House help & 4.0 & 1.7 \\
\hline Teacher* & 3.9 & 4.4 \\
\hline Sales person & 3.3 & 2.7 \\
\hline Cleaner & 3.0 & 2.7 \\
\hline $\begin{array}{l}\text { Non-agricultural } \\
\text { business* }\end{array}$ & 2.8 & 4.7 \\
\hline Hotel & 2.4 & 1.9 \\
\hline Waiter/cook & 2.3 & 2.1 \\
\hline $\begin{array}{l}\text { Retail shop/kiosk/ } \\
\text { shopkeeping }\end{array}$ & 2.2 & 1.7 \\
\hline Hairdresser/barber* & 1.4 & 1.9 \\
\hline Driver* & 1.1 & 1.7 \\
\hline Soldier* & 1.1 & 1.5 \\
\hline Electrician & 1.0 & 1.0 \\
\hline
\end{tabular}

\section{Support to Family and Network in Villages of Origin}

When asked about their pre-migration intentions, 67 percent of survey respondents indicated a desire to send money back to their family. Our data indicate that youths generally did provide remittances to their families back at home after providing for their own basic needs. In fact, 77 percent of youths indicated that they provide support to their family via cash, and 70 percent provide family via in-kind support (payment for sibling school fees, items from the city, etc.). Further, youths who migrated indicated an ability to support new youth migrants from their village of origin; 86 percent indicated they provided advice, and 78 percent provided connections with others in the urban areas. Additionally, 69 percent stated that they provided housing for new youth migrants from their village, and 73 percent provided financial assistance. Family remittances and support to new migrants indicate a community basis for migration, as well as continued social network ties to their villages.

\section{Interest in Returning to the Village}

When asked where they would like to move in the next 12 months, 41 percent of male survey respondents currently in Nairobi indicated they would move back to their village. Similarly, 76 percent of male survey respondents in Nairobi responded that they would like to return to their villages permanently in the future. Female survey respondents in both Nairobi and Bungoma were less likely than males to want to return to the village, and few males (12 percent) currently in Bungoma Town wanted to return to the village in the next 12 months, though more (51 percent) indicated an interest in returning permanently at some point in the future (Table 6).

Men who are currently married are also more likely than unmarried men to indicate an interest in

\section{Table 6. Survey respondents' interest in returning to their home villages}

\begin{tabular}{|c|c|c|c|c|}
\hline \multirow[b]{2}{*}{ Responses } & \multicolumn{2}{|c|}{ Nairobi } & \multicolumn{2}{|c|}{ Bungoma Town } \\
\hline & Male & Female & Male & Female \\
\hline$n$ & 487 & 162 & 417 & 284 \\
\hline \multicolumn{5}{|c|}{ If you had the choice of where to live in the next 12 months, would you: } \\
\hline Stay in current location & $41 \%$ & $52 \%$ & $49 \%$ & $54 \%$ \\
\hline Go back to the village & $41 \%$ & $29 \%$ & $12 \%$ & $4 \%$ \\
\hline Move to another town & $10 \%$ & $9 \%$ & $20 \%$ & $22 \%$ \\
\hline Move to another city & $4 \%$ & $8 \%$ & $18 \%$ & $18 \%$ \\
\hline \multicolumn{5}{|c|}{ Do you plan to return to your home village to settle permanently at any point in the future? } \\
\hline Yes & $76 \%$ & $41 \%$ & $51 \%$ & $16 \%$ \\
\hline
\end{tabular}


returning to their villages. We looked for associations between respondents' land ownership and primary economic activities with their desire to return to the village but did not find a relationship, most likely due to the lack of variation in those variables. We also did not find a relationship between respondents' age and their answer to these questions.

The desire to return to the village could be a result of the migration experience not meeting expectations. The focus groups revealed that migrants experienced some surprises in terms of security concerns, low earnings, and expensive, low-quality housing. Some women noted concerns around immorality.

Female respondents largely did not indicate an interest in returning to their home villages. One focus group participant noted that since the devolution of government from national to the county level in 2013, opportunities in regional town centers have increased.

We explored respondents' interest in returning to the village in relationship to their current employment, wages, and interest levels in various economic activities. Among males, 80 percent of those employed as watchmen at the time of the survey (the most common job for males) indicated a preference for returning to their village. Similarly, 72 percent of male casual workers said they wanted to return to their village. Key informant interviews in Bungoma Town indicated that those who return to the village are often those who cannot get jobs in the city, but the survey showed that unemployment in towns and cities is not associated with whether males plan to return home. Only 55 percent of currently unemployed male respondents planned to return to the village (and 61 percent of those who experienced unemployment in the last year), meaning that more watchmen or casual workers state an interest in returning to the village than do those who do not currently have a job.

Though our survey was limited in its ability to capture accurate wage data for respondents, we did ask them to estimate their average monthly pay within six broad pay categories. The median wage of those who plan to return to the village was higher than the median wage of those who do not, but the distribution of wages is similar between the two groups, so low wages do not seem to be a factor explaining youth migrants' interest in returning home.

To test the common notion that youth migrants are not interested in agriculture, we asked respondents about their level of interest in the most common economic activity for young adults in their village. Surprisingly, among respondents who said the most common activity for youth in their village is crop farming, 77 percent responded that they are "very interested" in that work (Table 7). Response rates were similarly high for livestock keeping (64 percent) and a combination of crop farming and livestock keeping ( 68 percent). Furthermore, 65 percent of men and 42 percent of women had returned to their village for agriculture-related work within the year preceding the survey.

We also surveyed respondents about what types of training they would be most interested in. Among male respondents from Bungoma, the most common response was training in driving or trucking

Table 7. Youths' level of interest in the most common economic activity for young people in their village of origin

\begin{tabular}{l|c|c|c}
\multirow{2}{*}{ Economic activity } & \multicolumn{3}{|c}{ Respondent level of interest \% $(\boldsymbol{n})$} \\
\cline { 2 - 4 } Crop farming & Very interested & Somewhat interested & Not at all interested \\
\hline Livestock keeping & $77 \%(129)$ & $11 \%(19)$ & $12 \%(20)$ \\
\hline $\begin{array}{l}\text { Combination of crop farming and } \\
\text { livestock keeping }\end{array}$ & $64 \%(7)$ & $18 \%(2)$ & $18 \%(2)$ \\
\hline Wage employed & $68 \%(194)$ & $20 \%(58)$ & $12 \%(33)$ \\
\hline Self-employed (non-agriculture) & $31 \%(105)$ & $25 \%(86)$ & $42 \%(143)$ \\
\hline
\end{tabular}

Respondents provided their level of interest in what they perceived to be the most common economic activity for youth in their village. Percentages are calculated conditional on having selected the economic activity. 
(35 percent), though that figure was slightly lower for those who indicated a plan to settle in their home villages (26 percent). Business management and computer or information and communications technology training were the next most common responses. Few Bungoma men responded with interest in agriculture-related training. Even among those with plans to settle in their home village, only 6.3 percent indicated an interest in training related to farming, agribusiness, or agro-processing.

We found mixed evidence supporting whether the purpose of migration was linked to a desire to reinvest in the farm or other rural livelihoods. In the focus group discussions, we heard that youths migrate to earn the money needed to invest in farm inputs. The focus groups also revealed that youth migrants borrow money to invest in land in or build houses in their villages. On the other hand, only 5.4 percent of survey respondents were saving money to return home (an additional 3 percent were saving to buy or develop land or build a house but did not specify whether in their village or elsewhere).

\section{Discussion and Conclusions}

Our survey results show that many youth who migrate from predominantly agricultural areas have plans to return to their home villages and are interested in agriculture. This finding was surprising in light of existing literature and the commonly held assumption that youth are abandoning agriculture and rural life. It further highlights that for some, migration to more urban areas is a phase in life. Interestingly, our survey results around preference for agriculture also differed from the findings of our focus group discussions, which echoed the literature: focus group participants described agriculture as "dirty work," for "old people," and "an old way of investing." This underscores the importance of using mixed methods that include sufficient sample size to draw conclusions.

The literature points to land access as a factor that deters Kenyan youth from agricultural livelihoods (Njenga et al., 2012; Oucho et al., 2014; Mwangi et al., 2016; Noorani, 2015; Osti et al., 2015) but does not link land access to migration. Our data indicate that access to land is not a driving factor behind youth migration out of rural areas. Further, only 16.5 percent of survey respondents indicated they would return to their village if they were to inherit land. Focus group participants noted that in Bungoma, youth from households with sufficient land tend not to migrate; if youth are entrepreneurial or profitably engaged in farming activities, they remain in the village. Our survey data show that access to land is not a factor driving out-migration, and we find that out-migration does not mean that youth are abandoning agriculture-many are very interested in agriculture, and most young men plan to return to the village.

While we do not know whether these youth will follow through on their plans to return to the village, their stated interest in agriculture could be harnessed for a productive contribution to the agricultural workforce. Very few survey respondents were currently employed in agriculture-related activities (though many return home for seasonal work); most are watchmen, casual workers, or unemployed, suggesting a mismatch between their interests and skills and their contribution to the workforce.

Programs aimed at engaging youth in productive employment in agricultural value chains should consider how to tailor support for this specific cohort that may offer unique skills (based on their agricultural origin and desire to return to the village) and connections to rural areas and-if their plans come to fruition-may return to agricultural livelihoods in the future. More information on individuals' specific goals would be required to identify what resources would best support them in their return to the village. Because many seem interested in owning land, key resources could include entrepreneurship training, access to land or land rights, access to appropriate financial services and agricultural inputs, training on end market quality standards and supply chains, or training in collective bargaining skills.

While conducting this research, we asked ourselves, What conditions enable one person to move, while others are constrained? What keeps people in certain places? We recognized that for many youth, family pressures (both negative and positive) pushed them to 
leave their home villages. That said, not only was their practical preparation limited primarily to earning enough for the initial migration, youth migrants also lack social or emotional preparation. Youths in the focus groups indicated that they would have liked more emotional support and regular communication with family members.

Overall, this research indicates that youth migration should be seen as fluid rather than static. While many youth continue to move from city to city, others return to home counties and home villages. Policy makers, service providers (skills building, training, family planning, etc.), employers, and development practitioners should engage youth using methods that recognize the mobility of this set of individuals.

What might this look like? Training institutes could offer courses that could be started in one location and finished in another. Family planning and life skills providers could employ a more targeted case management approach using a central database: technology innovations make this feasible even in rural areas. Employers may consider casting a wider net while searching for young employees. Given that many youth take 6 months to find a job and change jobs multiple times, basic household budgeting skills could benefit them in terms of motivations to migrate, keep a job, attain new skills, or save money.

Development practitioners should recognize that geographic intervention sites could be broader than geographically focused outcomes. For example, implementers of activities focused on growth of the agricultural sector in Bungoma may consider recruiting Bungoma migrants in Nairobi. They might more carefully consider the flow of remittances between Bungoma migrants and their family back home and target migrants as the purchasers of new types of seed or fertilizers that they can bring back home to their family members.

Finally, a key takeaway is that migration is inevitable for a subset of the youth population in rural areas in these counties in Kenya, and it should not be viewed with a negative lens. Research indicates that young adults are part of complex household and community resilience mechanisms. However, they lack the foundational and ongoing support to achieve what they visualize for themselves. This should be an area of interest for both policymakers and development implementers.

\section{Suggestions for Further Research}

This study provides insights into a specific, hardto-reach youth subpopulation-those born in agricultural areas who migrate to large towns and cities - that is often missed by research and development activities. Additional research could further inform policy and implementation in the following areas.

\section{Returning to Home Villages}

Although the data indicate that most male youth migrants are interested in agriculture and plan to return to their villages, we cannot draw conclusions from this dataset about how many follow through on these stated plans. Further research that follows youths over time and that continues to trace their migration and employment pathways would be required. Most youth who express interest in returning to their village within 12 months are currently working in jobs with limited growth potential (watchman, casual laborer). The promises of county-level growth due to devolution have also been cited as potentially enticing young adults to return from Nairobi.

\section{Household and Community Resilience}

Most of our respondents support their families in their home villages, with many also supporting additional youths from those villages both financially and as mentors. The focus group discussions also indicated a strong connection to the village of origin, with many participants noting that they preferred the social networks and community support to the isolation of urban areas. Research could be conducted on the food security and economic profiles of the village families and communities and whether such support enables households and/or communities to better absorb or adapt to shocks and stressors. Researchers could look into the cyclical nature of generations of young men migrating between home villages and urban areas. Finally, more research could be done on the social pressures pushing young 
migrants toward a perception of success vis-à-vis remittances and gifts and what perception they face if they return to their village permanently.

\section{Gender Considerations}

Our study used the same tool for both male and female youth migrants. Given that so few women indicated interest in returning to their home villages, as well as differences in woman's migration profiles (e.g., migration for marriage), further research using gender-specific surveys would better illuminate the migration experience of females. Focus group discussions noted that both young male and female migrants noted the potential for sexual exploitation as being an issue that young women frequently face. Women also noted that returning to their home village would be more difficult if they were perceived to have turned to prostitution to succeed in the city. Additional research is needed to understand the specific risks young women face, as well as societal pressures such as hierarchy and respect for elders, among others, that increase vulnerability for female migrants.

\section{Countering Violent Extremism}

Literature on countering violent extremism in Kenya highlights the importance of social networks, relationships between civil society and the public sector, and intergenerational support as increasing community resilience to radicalization (International Alert, 2016). The focus group participants noted that many youth would like greater communication with their parents and community back home. While this study was not focused on issues of violent extremism, respondent-driven sampling may be a way in which to better learn about youth moving into specific crime hot-spot neighborhoods-such as Eastleigh, Nairobi-and what types of support they would need from their social networks, the government, and elders in their community.

\section{References}

Afande, F. O., Maina, W. N., \& Maina, M. P. (2015). Youth engagement in agriculture in Kenya: Challenges and prospects. Journal of Culture, Society and Development, 7, 4-19.

Commission on Revenue Allocation (Kenya). (2011). Kenya county fact sheets. Retrieved from https://www. slideshare.net/simbagoma/commission-of-revenuekenya-county-fact-sheets-dec-2011

County Government of Bungoma. (2013). First Bungoma County integrated development plan 2013-2017. Retrieved from http://cog.go.ke/downloads/category/82county-integrated-development-plans-2013-2017

Government of Kenya. (2009). Population and housing census. Nairobi, Kenya: Centre Bureau of Statistics.

Heckathorn, D. (2002). Respondent-driven sampling II: Deriving valid population estimates from chain-referral samples of hidden populations. Social Problems, 49(1), 11-34. https://doi.org/10.1525/sp.2002.49.1.11

International Alert. (2016). We don't trust anyone: Strengthening relationships as the key to reducing violent extremism in Kenya. Retrieved from https://www. international-alert.org/publications/we-dont-trustanyone
Kristensen, S. B. P., \& Birch-Thomsen, T. (2013). Should I stay or should I go? Rural youth employment in Uganda and Zambia. International Development Planning Review, 35(2), 175-201. https://doi.org/10.3828/ idpr.2013.12

Leavy, J., \& Hossain, N. (2014). Who wants to farm? Youth aspirations, opportunities and rising food prices. Institute of Development Studies Working Papers, 2014(439), 1-44. https://doi.org/10.1111/j.20400209.2014.00439.x

Miguel, E., \& Hamory, J. (2009). Individual ability and selection into migration in Kenya. United Nations Development Programme Human Development Research Paper 2009/45. http://hdr.undp.org/en/ content/individual-ability-and-selection-migrationkenya

Muyanga, M., Otieno, D., \& Jayne, T.S. (2016, September 23-26). Land access and outmigration in densely populated areas of rural Kenya. Invited paper presented at the 5th International Conference of the Africa Association of Agricultural Economists, Addis Ababa, Ethiopia. 
Mwangi, G. M., Ng’etich, K. A., \& Apollos, F. M. (2016). Characteristics of youth attitudes toward farming in Kuresoi sub-county. Kenya: Nakuru County.

Njenga, P., Mugo, F., \& Opiyo, J. (2012). Youth and women empowerment through agriculture in Kenya. Voluntary Service-Overseas. Nairobi, Kenya: VSO-Jitolee.

Noorani, M. (2015). To farm or not to farm? Rural youth perceptions of farming and their decision of whether or not to work as a farmer: A case study of rural youth in Kiambu County, Kenya (Doctoral dissertation, Université d'Ottawa/University of Ottawa). https://doi. org/10.20381/ruor-2719

Osti, A., van t Land, J., Magwegwe, D., Peereboom, A., van Oord, J., \& Dusart, T. (2015). The future of youth in agricultural value chains in Ethiopia and Kenya. http:// www.fairandsustainable.nl/wp-content/uploads/2015/11/ REPORT-The-future-of-youth-in-agricultural-valuechains-in-Ethiopia-and-Kenya-Final.pdf

Oucho, J. O., Oucho, L. A., \& Ochieng, V. (2014). Is migration the solution to poverty alleviation in Kenya? Rural-urban migration experiences of migrants from Western Kenya to Kisumu and Nairobi (Migrating out of Poverty RPC Working Paper 21). Brighton, UK: Migrating out of Poverty Consortium, University of Sussex.
Republic of Kenya Ministry of Agriculture, Livestock and Fisheries. (2017). Kenya youth agribusiness strategy 2017-2021. Retrieved from http://extwprlegs1.fao.org/ docs/pdf/ken171450.pdf

UN Habitat. (2018). UN habitat brief on migration and cities. Retrieved from https://unhabitat.org/wp-content/ uploads/2018/12/Migration_Brochure_10122018.pdf

United Nations Development Programme. (2018). Human development indices and indicators: 2018 statistical update. Retrieved from https://africacheck.org/wpcontent/uploads/2018/09/2018_human_development_ statistical_update.pdf

Yeboah, F. K. (2018). Youth for growth: Transforming economies through agriculture. Chicago Council on Global Affairs. Retrieved from https://www. thechicagocouncil.org/sites/default/files/report_youthfor-growth_exec-summary_20180322.pdf 


\section{Appendix}

\section{Kenya Youth in Migration Survey}

\section{INTRODUCTION}

\section{READ THE FOLLOWING WORD-FOR-WORD TO THE RESPONDENT:}

You are being asked to participate in a research study. This study is being conducted by Research Solutions Africa, a research organization based in Nairobi and RTI International, a research organization in the USA.

The purpose of this study is to understand the opportunities and challenges of migrant youth populations in Nairobi, Bungoma and Garissa. If you agree to participate, I'll ask you questions about your migration experience. The survey takes about 30-45 minutes to complete.

This research study is voluntary. You can stop at any time, refuse to answer any question, or take a break. Your answers are confidential. I'll give you a gift for your time if you are eligible to participate and complete the interview.

If you have any questions about this research, please contact [information removed.]

Do you have any questions about what I just told you? ANSWER ANY QUESTIONS.

Do you want to participate in the study?

$\square$ Yes $\quad \square$ No

[IF YES CONTINUE TO INTERVIEW INFORMATION. IF NO: END INTERVIEW]

\section{INTERVIEW INFORMATION}

RESPONDENT NAME:

RESPONDENT'S PHONE NUMBER:

PLACE OF INTERVIEW (Area/estate):

INVITATION ID:

RESPONDENT ID:

INTERVIEWER NAME:

Date:

Time Start: 


\section{SECTION A: SCREENER INTERVIEW}

Before we start the interview, I have some questions about you.

\section{INTERVIEWER: [RECORD RESPONDENT GENDER]}

1 MALE

2 FEMALE

2. How old are you? -8 DON'T KNOW -9 REFUSED

[RECORD NUMBER] [IF LESS THAN 18 OR GREATER THAN 35, DON'T KNOW, OR REFUSED, TERMINATE THE INTERVIEW]

3. Where do you currently live?

1 Nairobi

2 Bungoma Town

3 Garissa Town

[IF 4, -8, or -9, TERMINATE THE INTERVIEW]
4 Other (specify)
-8 DON'T KNOW
-9 REFUSED

4. In which county were you born?
1 Bungoma County
-8 DON'T KNOW
2 Garissa County
-9 REFUSED
3 Other (specify)

[IF BIRTH COUNTY IS NOT BUNGOMA OR GARISSA COUNTY, DON'T KNOW, OR REFUSED, TERMINATE THE INTERVIEW]

5. Before the age of 12 , did you live in [FILL FROM Q4] town or in a village?
1 Village (specify)
3 Garissa

2 Bungoma

[By live, we mean the place where the respondent spent most of their time or resided before the age of 12.$]$

6. Were you married when you first moved from [FILL FROM Q5_1] to [FILL FROM Q3]?
1 Yes
-8 DON'T KNOW
2 No
-9 REFUSED

[IF WOMEN SAY 1, TERMINATE INTERVIEW. IF WOMEN SAY 2, CONTINUE INTERVIEW. IF MEN ANSWER 1, 2, -8 , OR -9, CONTINUE INTERVIEW]

[TERMINATION CLAUSE: "Your response indicates that you are not eligible to participate in the survey. Thank you for your time and understanding."] 


\section{SECTION B: INDIVIDUAL CHARACTERISTICS}

7. What is your current marital status? READ RESPONSE OPTIONS
1 Single
5 Widowed
2 Married
-8 DON'T KNOW
3 Separated
-9 REFUSED

4 Divorced

8. What is the highest level of education that you completed?
1 No education
5 Secondary
2 Some Primary
6 Higher than secondary
3 Primary
-8 DON'T KNOW
4 Some secondary
-9 REFUSED

9. Are you able to read a book in any language?
1 YES
-8 DON'T KNOW
$2 \mathrm{NO}$
-9 REFUSED

[If 1 , GO TO 10. IF 2, -8, or -9, GO TO Q11]

10. In which language(s) can you read a book? READ RESPONSE OPTIONS

\begin{tabular}{|l|c|c|c|c|}
\hline & YES & NO & DON'T KNOW & REFUSED \\
& $\mathbf{1}$ & $\mathbf{2}$ & $\mathbf{- 8}$ & $\mathbf{- 9}$ \\
\hline English & $\square$ & $\square$ & $\square$ & $\square$ \\
\hline Kiswahili & $\square$ & $\square$ & $\square$ & $\square$ \\
\hline Somali & $\square$ & $\square$ & $\square$ & $\square$ \\
\hline Mother tongue & $\square$ & $\square$ & $\square$ & $\square$ \\
\hline
\end{tabular}


11. Now we'd like information about the places that you have lived since you were 12. By places that you have lived, we mean a place that you stayed for at least one month for education, work, or a search for employment. Let's start by thinking about the place that you live now.

[IF RESPONDENT HAS LIVED IN ANY LOCATION FOR LESS THAN A YEAR, PLEASE WRITE THE NUMBER OF MONTHS, FOR EXAMPLE, 8 MONTHS.]

\begin{tabular}{|c|c|c|c|c|c|c|}
\hline & $\begin{array}{l}\text { Place of destination (town or } \\
\text { city) }\end{array}$ & $\begin{array}{l}\text { Month of } \\
\text { arrival }\end{array}$ & $\begin{array}{l}\text { Year of } \\
\text { arrival }\end{array}$ & $\begin{array}{c}\text { How } \\
\text { long? } \\
\text { (years) }\end{array}$ & $\begin{array}{c}\text { How } \\
\text { long? } \\
\text { (months) }\end{array}$ & $\begin{array}{l}\text { Main economic activity } \\
\text { (choose from list below) }\end{array}$ \\
\hline 1 & & & & & & \\
\hline 2 & & & & & & \\
\hline 3 & & & & & & \\
\hline 4 & & & & & & \\
\hline 5 & & & & & & \\
\hline
\end{tabular}

-8 DON'T KNOW

-9 REFUSED

Main Economic Activity List

1 Crop farming

2 Livestock keeping

3 Combination of crop farming and livestock keeping

4 Wage employed

5 Self-employed (non-agriculture)

6 Family business (non-agriculture)
7 Education

8 Unemployed

9 Other (specify)

-8 DON'T KNOW

-9 REFUSED

12. If you had the choice of where to live in the next 12 months, would you...?

\section{READ RESPONSE OPTIONS}

1 Stay in [FILL FROM Q3]

2 Go back to the village

3 Move to another town
4 Move to another city

-8 DON'T KNOW

-9 REFUSED

13. Do you plan to return to [FILL FROM Q5_1] to settle permanently at any point in the future?
1 YES
-8 DON'T KNOW
$2 \mathrm{NO}$
-9 REFUSED 
14. Would you return to the village permanently if any of the following happened? READ RESPONSE OPTIONS

\begin{tabular}{|c|c|c|c|c|}
\hline & $\begin{array}{c}\text { YES } \\
1\end{array}$ & $\begin{array}{c}\text { NO } \\
2\end{array}$ & $\begin{array}{c}\text { DON'T KNOW } \\
-8\end{array}$ & $\begin{array}{c}\text { REFUSED } \\
-9\end{array}$ \\
\hline Death of a family member & $\square$ & $\square$ & $\square$ & $\square$ \\
\hline Sickness of a family member & $\square$ & $\square$ & $\square$ & $\square$ \\
\hline Inherit land & $\square$ & $\square$ & $\square$ & $\square$ \\
\hline Lose current job & $\square$ & $\square$ & $\square$ & $\square$ \\
\hline Get married & $\square$ & $\square$ & $\square$ & $\square$ \\
\hline
\end{tabular}

15. What is your occupation, that is, what kind of work do you mainly do? [REFER TO THE JOB LIST AND RECORD NUMBER]

16. Have you done any work for pay in the last seven days?
1 YES
-8 DON'T KNOW
$2 \mathrm{NO}$
-9 REFUSED

[IF 1, GO TO 17. IF 2 , GO TO 16B. IF -8, or -9 , GO TO Q18]

16b. If no, please explain.

1 Leave (sick, annual, maternity, etc.)

3 Other (specify)

2 Unemployed

17. What is your average pay (in KShs.) for a month?

1 Less than 1,000

21,000 to 4,999

35,000 to 9,999

410,000 to 14,999
515,000 to 19,999

6 More than 20,000

-8 DON'T KNOW

-9 REFUSED 
18. Now, we'd like to ask you about your work history for the past 12 months. Please think about any work that you have done in the past 12 months, since this time last year. Start with your most recent position(s) to the position(s) you held 12 months ago. If you worked more than one job at any point, please let me know.

[IF THERE HAS BEEN NO CHANGE IN EMPLOYMENT STATUS, PUT “PRESENT" IN THE END MONTH FIELD]

\begin{tabular}{|c|c|c|c|c|c|c|c|}
\hline & $\begin{array}{l}\text { Location (Nairobi, Bungoma } \\
\text { Town, Garissa Town, Home } \\
\text { Village, Other) }\end{array}$ & $\begin{array}{c}\text { Main } \\
\text { economic } \\
\text { activity } \\
\text { (choose from } \\
\text { list below) }\end{array}$ & $\begin{array}{c}\text { Start } \\
\text { month }\end{array}$ & $\begin{array}{l}\text { Start } \\
\text { year }\end{array}$ & $\begin{array}{c}\text { End } \\
\text { month }\end{array}$ & $\begin{array}{l}\text { End } \\
\text { year }\end{array}$ & $\begin{array}{c}\text { Hours } \\
\text { worked } \\
\text { per week }\end{array}$ \\
\hline 1 & & & & & & & \\
\hline 2 & & & & & & & \\
\hline 3 & & & & & & & \\
\hline 4 & & & & & & & \\
\hline 5 & & & & & & & \\
\hline 6 & & & & & & & \\
\hline 7 & & & & & & & \\
\hline 8 & & & & & & & \\
\hline
\end{tabular}

-8 Don't Know

1 Crop farming

2 Livestock keeping

3 Combination of crop farming and livestock keeping

4 Wage employed education

5 Self-employed (non-agriculture)

6 Family business (non-agriculture)
-9 Refused

7 Education

8 Unemployed [SKIP HOURS PER WEEK]

9 Other (specify)

-8 DON'T KNOW

-9 REFUSED

19. Were you ever unemployed in the last 12 months?
1 YES
-8 DON'T KNOW
$2 \mathrm{NO}$
-9 REFUSED

[If 1, go to Q20. If $2,-8$, or -9 , go to $Q 21]$ 
20. What was the main reason you were not working during your last period of unemployment? READ RESPONSE OPTIONS

1 Sick

2 Business closed

3 Looking for work

4 Out of season

5 Retrenchment/Redundancy

6 Temporary lay off
7 Did not need to work

8 Did not want to work

9 Full-time student

10 Retired

-8 DON'T KNOW

-9 REFUSED

21. At any point during the past 12 months, have you returned to [FILL FROM Q5_1] for agricultural or livestock-related work?
1 YES
-8 DON'T KNOW
$2 \mathrm{NO}$
-9 REFUSED

\section{SECTION C: CHARACTERISTICS OF PRE-MIGRATION HOUSEHOLD (at the time of first move)}

The next questions are about your household the first time you moved away from your village for more than a month. We are referring to the household in [FILL FROM Q5_1].

[A HOUSEHOLD CONSISTS OF A PERSON OR GROUPS OF PERSONS, IRRESPECTIVE OF WHETHER RELATED OR NOT, WHO NORMALLY LIVE TOGETHER IN THE SAME HOUSING UNITS OR GROUP OF HOUSING UNITS AND HAVE COMMON COOKING AND EATING ARRANGEMENTS.]

22. Did your ever move outside of [FILL FROM Q5_1]?

\begin{tabular}{|c|c|c|c|c|c|}
\hline Name & $\begin{array}{c}\text { YES } \\
1\end{array}$ & $\begin{array}{c}\text { NO } \\
2\end{array}$ & $\begin{array}{c}\text { Not Applicable } \\
3\end{array}$ & $\begin{array}{c}\text { DON'T KNOW } \\
-8\end{array}$ & $\begin{array}{c}\text { REFUSED } \\
-9\end{array}$ \\
\hline Father & $\square$ & $\square$ & $\square$ & $\square$ & $\square$ \\
\hline Mother & $\square$ & $\square$ & $\square$ & $\square$ & $\square$ \\
\hline Older siblings & $\square$ & $\square$ & $\square$ & $\square$ & $\square$ \\
\hline Younger siblings & $\square$ & $\square$ & $\square$ & $\square$ & $\square$ \\
\hline Uncles, aunts, cousins & $\square$ & $\square$ & $\square$ & $\square$ & $\square$ \\
\hline
\end{tabular}


23. Did you make any of the following arrangements before migrating from [FILL FROM Q5_1]?

\begin{tabular}{|c|c|c|c|c|}
\hline & $\begin{array}{c}\text { YES } \\
1\end{array}$ & $\begin{array}{c}\text { NO } \\
2\end{array}$ & $\begin{array}{c}\text { DON'T KNOW } \\
-8\end{array}$ & $\begin{array}{c}\text { REFUSED } \\
-9\end{array}$ \\
\hline Saved money to move & $\square$ & $\square$ & $\square$ & $\square$ \\
\hline Borrowed money to move & $\square$ & $\square$ & $\square$ & $\square$ \\
\hline Looked at training or skills development programs & $\square$ & $\square$ & $\square$ & $\square$ \\
\hline Enrolled in training or skills development programs & $\square$ & $\square$ & $\square$ & $\square$ \\
\hline Enquired about job opportunities & $\square$ & $\square$ & $\square$ & $\square$ \\
\hline Made contact with family or social networks & $\square$ & $\square$ & $\square$ & $\square$ \\
\hline Identified housing & $\square$ & $\square$ & $\square$ & $\square$ \\
\hline
\end{tabular}

24. Now, imagine you have a friend who would like to move from the village. What should your friend do before the move? READ RESPONSE OPTIONS

1 Save money

2 Borrow money

3 Enroll in training or skills development programs

4 Research job opportunities in your destination town or city

5 Make contact with family or social networks in destination town or city
6 Identify housing in destination town or city

7 Other (specify)

-8 DON'T KNOW

-9 REFUSED

25. At the time that you first left [FILL FROM Q5_1], what was the main economic activity in your household? READ RESPONSE OPTIONS

1 Crop farming

2 Livestock keeping

3 Combination of crop farming and livestock keeping

4 Wage employed

5 Self-employed (non-agriculture)

6 Family business (non-agriculture)
7 Education

8 Unemployed

9 Other (specify)

-8 DON'T KNOW

-9 REFUSED

26. At the time that you first left [FILL FROM Q5_1], did any member of your household own any agricultural land?
1 YES
-8 DON'T KNOW
$2 \mathrm{NO}$
-9 REFUSED

[If 1, go to Q27. If 2, -8, or -9, go to Q28] 
27. How many acres or hectares of agricultural land did members of your household own at the time that you first left [FILL FROM Q5_1]?
-8 DON'T KNOW
-9 REFUSED

[Open entry in case person only says $50 \mathrm{~m} \times 100 \mathrm{~m}$ - button to click acres or hectares]

28. At the time that you first left [FILL FROM Q5_1], what was your household roof made of? READ RESPONSE OPTIONS

1 Metal, tin, or zinc

2 Tiles

3 Thatch or grass

4 Multiple materials
5 Some other material

-8 DON'T KNOW

-9 REFUSED

\section{SECTION D: VILLAGE OF ORIGIN CHARACTERISTICS}

The next questions are about [FILL FROM Q5_1] as it is today.

29. Currently, what is the primary economic activity in [FILL FROM Q5_1]?

\section{READ RESPONSE OPTIONS}

1 Crop farming

2 Livestock keeping

3 Combination of crop farming and livestock keeping

4 Wage employed

5 Self-employed (non-agriculture)
6 Family business (non-agriculture)

7 Unemployed

8 Other (specify)

-8 DON'T KNOW

-9 REFUSED

30. What is the most common economic activity for young adults between 18 and 35 who live in [FILL FROM Q5_1]? READ RESPONSE OPTIONS

1 Crop farming

2 Livestock keeping

3 Combination of crop farming and livestock keeping

4 Wage employed

5 Self-employed (non-agriculture)
6 Family business (non-agriculture)

7 Unemployed

8 Other (specify)

-8 DON'T KNOW

-9 REFUSED 
31. How interested are you in [FILL FROM Q30] work? READ RESPONSE OPTIONS

1 Very interested

2 Somewhat interested

3 Not at all interested
-8 DON'T KNOW

-9 REFUSED

\section{SECTION E: MIGRATION}

Now l'd like to talk to you about your last move to [FILL FROM Q3].

32. Did you move to [FILL FROM Q3] alone or with someone else?
1 By myself
-8 DON'T KNOW
2 Someone else
-9 REFUSED

33. What was the main purpose for the move to [FILL FROM Q3]?

1 Education

2 Search for work

3 Job opportunity

4 Job transfer

5 Civil conflict/War/Political factors

6 Marriage

7 Divorce/Marriage dissolution

8 Death of spouse or partner

9 Moved to join other family members
10 Return to original or previous home

11 Do not own agricultural land to work in village/ Don't have enough land

12 Lack of services

13 Health problems

14 Drought

15 Other (specify)

-8 DON'T KNOW

-9 REFUSED 
34. How important were the following factors in influencing your decision to move to [FILL FROM Q3]? READ RESPONSE OPTIONS

\begin{tabular}{|l|c|c|c|c|c|c|}
\hline & $\begin{array}{c}\text { Very } \\
\text { Important } \\
\mathbf{1}\end{array}$ & $\begin{array}{c}\text { Important } \\
\mathbf{2}\end{array}$ & $\begin{array}{c}\text { Slightly } \\
\text { Important } \\
\mathbf{3}\end{array}$ & $\begin{array}{c}\text { Not } \\
\text { Important } \\
\mathbf{4}\end{array}$ & $\begin{array}{c}\text { DON'T } \\
\text { KNOW } \\
-\mathbf{8}\end{array}$ & $\begin{array}{c}\text { REFUSED } \\
-9\end{array}$ \\
\hline $\begin{array}{l}\text { Could not find employment/ } \\
\text { generate income in } \\
\text { [FILL FROM Q5_1] }\end{array}$ & $\square$ & $\square$ & $\square$ & $\square$ & $\square$ \\
\hline $\begin{array}{l}\text { Prefer employment opportunities } \\
\text { available in larger towns/cities }\end{array}$ & $\square$ & $\square$ & $\square$ & $\square$ & $\square$ & $\square$ \\
\hline $\begin{array}{l}\text { Family or social network in } \\
\text { [FILL FROM Q3] location }\end{array}$ & $\square$ & $\square$ & $\square$ & $\square$ & $\square$ & $\square$ \\
\hline $\begin{array}{l}\text { Lack of access to land in } \\
\text { [FILL FROM Q5_1] }\end{array}$ & $\square$ & $\square$ & $\square$ & $\square$ & $\square$ & $\square$ \\
\hline $\begin{array}{l}\text { Desire to send money back to } \\
\text { family in [FILL FROM Q5_1] }\end{array}$ & $\square$ & $\square$ & $\square$ & $\square$ & $\square$ & $\square$ \\
\hline $\begin{array}{l}\text { Poor living conditions in } \\
\text { [FILL FROM Q5_1] }\end{array}$ & $\square$ & $\square$ & $\square$ & $\square$ & $\square$ & $\square$ \\
\hline $\begin{array}{l}\text { Lack of training/ educational } \\
\text { opportunities available in } \\
\text { [FILL FROM Q5_1] }\end{array}$ & $\square$ & $\square$ & $\square$ & $\square$ & $\square$ & $\square$ \\
\hline
\end{tabular}

35. Did you talk to your

about your decision to move to [FILL FROM Q3]?

\begin{tabular}{|l|c|c|c|c|c|}
\hline & YES & NO & Not Applicable \\
$\mathbf{2}$ & $\mathbf{2}$ & $\square$ & $\begin{array}{c}\text { DON'T KNOW } \\
\mathbf{- 8}\end{array}$ & $\begin{array}{c}\text { REFUSED } \\
\mathbf{- 9}\end{array}$ \\
\hline Parents & $\square$ & $\square$ & $\square$ & $\square$ & $\square$ \\
\hline Extended family & $\square$ & $\square$ & $\square$ & $\square$ & $\square$ \\
\hline Community members & $\square$ & $\square$ & $\square$ & $\square$ & $\square$ \\
\hline Friends or peers & $\square$ & $\square$ & $\square$ & $\square$ & $\square$ \\
\hline Religious leaders & $\square$ & $\square$ & $\square$ & $\square$ & $\square$ \\
\hline
\end{tabular}

36. Did your parents tell you to move to [FILL FROM Q3]?

1 YES

2 NO

3 Not applicable
-8 DON'T KNOW

-9 REFUSED 
37. How long were you planning to stay in [FILL FROM Q3] when you first moved? READ RESPONSE OPTIONS

1 Less than 3 months

23 to 6 months

37 to 11 months

41 to 5 years
5 Indefinitely

-8 DON'T KNOW

-9 REFUSED

38. Did you make advance preparations for housing before you arrived in [FILL FROM Q3]?
1 YES
-8 DON'T KNOW
$2 \mathrm{NO}$
-9 REFUSED

39. When you first arrived in [FILL FROM Q3], who did you live with? READ RESPONSE OPTIONS
1 Friend
6 No one [SKIP TO Q44]
2 Employer
7 Other (specify)
3 Relative
-8 DON'T KNOW [SKIP TO Q44]
4 Spouse
-9 REFUSED [SKIP TO Q44]
5 School

40. Do you still live with [OPTION FOR Q39]?
1 YES
-8 DON'T KNOW
$2 \mathrm{NO}$
-9 REFUSED

[If 1, -8, -9, go to Q41. If 2, go to Q42]

41. How long have you lived with [OPTION FOR Q39]?

1 Less than 3 months

23 to 6 months

37 to 11 months

41 to 2 years

[ALL RESPONDENTS WHO ANSWER 41, GO TO 44]
5 More than 2 years

-8 DON'T KNOW

-9 REFUSED 
42. How long did you live with [OPTION FOR Q39]?

1 Less than 3 months

23 to 6 months

37 to 11 months

41 to 2 years

[ALL RESPONDENTS WHO ANSWER 42, GO TO 43]

43. How did you find your new housing?

1 Friend

2 Employer

3 Relative

4 Searching ads

5 Real estate agent
5 More than 2 years

-8 DON'T KNOW

-9 REFUSED

44. How many people do you currently live with in [FILL FROM Q3]? [RECORD NUMBER] [If 0 , go to Q48. If 1 or more than 1 , go to Q45]

45. Do you currently live with (a/an)
6 Spouse
7 Other (specify)
-8 DON'T KNOW
-9 REFUSED

\begin{tabular}{|c|c|c|c|c|}
\hline & $\begin{array}{c}\text { YES } \\
1\end{array}$ & $\begin{array}{c}\text { NO } \\
2\end{array}$ & $\begin{array}{c}\text { DON'T KNOW } \\
-8\end{array}$ & $\begin{array}{c}\text { REFUSED } \\
-9\end{array}$ \\
\hline Friend & $\square$ & $\square$ & $\square$ & $\square$ \\
\hline Employer & $\square$ & $\square$ & $\square$ & $\square$ \\
\hline Relative & $\square$ & $\square$ & $\square$ & $\square$ \\
\hline Stranger & $\square$ & $\square$ & $\square$ & $\square$ \\
\hline
\end{tabular}

46. Are you currently receiving any support like spending money, food, or school fees from the people that you live with?
1 YES
-8 DON'T KNOW
$2 \mathrm{NO}$
-9 REFUSED

47. Do you contribute to living costs like rent, water, food and electricity for your household in [FILL FROM Q3]?
1 YES
-8 DON'T KNOW
$2 \mathrm{NO}$
-9 REFUSED 
48. Which statement best describes the people you regularly talk to in [FILL FROM Q3]? READ RESPONSE OPTIONS

1 Mostly people I knew before I moved here

2 Mostly people from my village that I did not know before moving here

3 Mostly people I have met since moving here that are not from my village

[If 1, -8 or -9, go to Q50. If 2 or 3, go to Q49]
-8 DON'T KNOW

-9 REFUSED

49. How have you met most of the people you regularly talk to since moving to [FILL FROM Q3]? READ RESPONSE OPTIONS

1 Through work

2 Through social connections (FRIENDS OF FRIENDS)

3 Through family

4 Neighbors
5 Other (specify)

-8 DON'T KNOW

-9 REFUSED

\section{SECTION F: EMPLOYMENT}

Now we'd like to talk to you about your first job in [FILL FROM Q3].

50. What was your first job in [FILL FROM Q3]? [REFER TO THE JOB LIST AND RECORD NUMBER. IF RESPONDENT IS A STUDENT OR IS UNEMPLOYED, GO TO Q57]

51. How did you get your first job? READ RESPONSE OPTIONS

1 Searched by oneself

2 Recommended by a relative

3 Recommended by a friend

4 Through an employment agency

5 Responded to an advertisement
6 School or training

9 Other (specify)

-8 DON'T KNOW

-9 REFUSED

52. Thinking about your first job, was that the work you hoped to do when you moved to [FILL FROM Q3]?
1 YES
-8 DON'T KNOW
$2 \mathrm{NO}$
-9 REFUSED 
53. How long did it take you to get your first job in [FILL FROM Q3]? READ RESPONSE OPTION

1 Immediately

2 Less than 3 months

33 to 6 months

47 to 12 months
5 More than 1 years

-8 DON'T KNOW

-9 REFUSED

54. How long did you work at your first job? READ RESPONSE OPTIONS
1 Less than 3 months
5 Currently working at job
23 to 6 months
-8 DON'T KNOW
37 to 12 months
-9 REFUSED
4 More than 1 year

55. Did you know how much you would be paid before accepting your first job?
1 YES
-8 DON'T KNOW
$2 \mathrm{NO}$
-9 REFUSED

56. For your first job, was your salary lower, higher, or about what you expected?
1 Lower
4 I had no expectation
2 Higher
-8 DON'T KNOW
3 About what I expected
-9 REFUSED 


\section{SECTION G: EDUCATION}

[FOR RESPONDENTS WHO ANSWERED OPTION 99 (STUDENT) FOR Q15]

\section{What type of educational program are you currently enrolled in? READ RESPONSE OPTIONS}

$\begin{array}{ll}1 \text { Secondary school } & 6 \text { Middle-level commercial colleges } \\ 2 \text { Vocational training school (agriculture-related) } & 7 \text { Post-graduate studies } \\ 3 \text { Vocational training school (non-agricultural) } & 8 \text { Other (specify) } \\ 4 \text { University } & -8 \text { DON'T KNOW } \\ 5 \text { Technical school } & -9 \text { REFUSED }\end{array}$

58. What is the duration of the program? READ RESPONSE OPTIONS

1 Less than 6 months

26 to 11 months

31 to 2 years

4 More than 2 years
5 More than 4 years

-8 DON'T KNOW

-9 REFUSED

59. Did you enroll in the program prior to moving to [FILL FROM Q3]?
1 YES
-8 DON'T KNOW
$2 \mathrm{NO}$
-9 REFUSED

60. How did you learn about the program? READ RESPONSE OPTIONS
1 Family
5 Own research
2 Friends
6 Other (specify)
3 School
-8 DON'T KNOW
4 Marketing or promotion
-9 REFUSED

\section{How do you pay for the program? READ RESPONSE OPTIONS}

1 Parent or family support

2 Work

3 Financial aid or scholarship

4 Loans
5 It is a free program

6 Other (specify)

-8 DON'T KNOW

-9 REFUSED 


\section{What do you plan to do when the program is complete? READ RESPONSE OPTIONS}

1 Find a job in [FILL FROM Q3]

2 Find a job in another city

3 Return to [FILL FROM Q5_1]

4 Enroll in additional education
6 Other (specify)

-8 DON'T KNOW

-9 REFUSED

63. What type of job do you want to have when you complete your education? [REFER TO THE JOB LIST AND RECORD NUMBER]

\section{SECTION H: SKILLS}

64. Do you have access to training or skills development programs in [FILL FROM Q3]?
1 YES
-8 DON'T KNOW
$2 \mathrm{NO}$
-9 REFUSED

[If 1, go to $Q 65$. If $2,-8$, or -9 go to Q67]

65. What type of training or skills development programs are available to you?
1 Financial literacy/Money management
15 Chemicals \& chemical products (making detergents, shampoo, tie \& dye)
2 Entrepreneurship
16 Food \& beverage (baking, restaurant management)
3 Business management
17 Carpentry
4 Leadership skills
18 Building and construction
5 Life skills (including sexual and reproductive
19 Masonry
6 Engineering
20 Plumbing
7 Electrical/Electronics/Mobile phone repairs
21 Machine operator
8 Handicrafts - leather products, hand-weaving, beadwork
9 Sewing, tailoring or embroidery
22 Driver/Trucking
10 Farming - agricultural production techniques
23 Computer training /ICT
24 Other professional career (doctor, lawyer, NGO workers)
11 Agri-business (service provision such as inputs, transport, machinery)
12 Agro-processing (making honey, yoghurt, juice, peanut butter)
13 Hairdressing \& beauty
-8 DON'T KNOW
25 Other vocational skill program
-9 REFUSED

14 Metal work \& welding 


\section{Who offers the training or skills development programs? READ RESPONSE OPTIONS}

1 National government

2 County government

3 Businesses

4 NGOs (fee based)

5 Technical schools

6 Vocational schools
7 Universities

8 Middle-level commercial colleges

9 Agricultural training institutes

-8 DON'T KNOW

-9 REFUSED

\section{Are you interested in training or skills development programs?}

1 YES

-8 DON'T KNOW

$2 \mathrm{NO}$

-9 REFUSED

[If 1 , go to 68. If $2,-8$, or -9 , go to Q73]

\section{What type of training or skills development programs are you interested in?}

1 Financial literacy/Money management

2 Entrepreneurship

3 Business management

4 Leadership skills

5 Life skills (including sexual and reproductive health, conflict resolutions, eating healthy)

6 Engineering

7 Electrical/Electronics/Mobile phone repairs

8 Handicrafts - leather products, hand-weaving, beadwork

9 Sewing, tailoring or embroidery

10 Farming - agricultural production techniques

11 Agri-business (service provision such as inputs, transport, machinery)

12 Agro-processing (making honey, yoghurt, juice, peanut butter)

13 Hairdressing \& beauty

14 Metal work \& welding
15 Chemicals \& chemical products (making detergents, shampoo, tie \& dye)

16 Food \& beverage (baking, restaurant management)

17 Carpentry

18 Building and construction

19 Masonry

20 Plumbing

21 Machine operator

22 Driver/Trucking

23 Computer training /ICT

24 Other professional career (doctor, lawyer, NGO workers)

25 Other vocational skill program

-8 DON'T KNOW

-9 REFUSED 
69. Now we'd like to talk about the factors that would be most important to you before deciding to pursue training. Is/are a major factor, minor factor, or not a factor?

\begin{tabular}{|l|c|c|c|c|c|}
\hline & $\begin{array}{c}\text { Major factor } \\
\mathbf{1}\end{array}$ & $\begin{array}{c}\text { Minor factor } \\
\mathbf{2}\end{array}$ & $\begin{array}{c}\text { Not a factor } \\
\mathbf{3}\end{array}$ & $\begin{array}{c}\text { DON'T KNOW } \\
\mathbf{- 8}\end{array}$ & $\begin{array}{c}\text { REFUSED } \\
\mathbf{- 9}\end{array}$ \\
\hline Entry requirements & $\square$ & $\square$ & $\square$ & $\square$ & $\square$ \\
\hline Ease of application process & $\square$ & $\square$ & $\square$ & $\square$ & $\square$ \\
\hline Cost & $\square$ & $\square$ & $\square$ & $\square$ & $\square$ \\
\hline Schedule & $\square$ & $\square$ & $\square$ & $\square$ & $\square$ \\
\hline Proximity to home & $\square$ & $\square$ & $\square$ & $\square$ & $\square$ \\
\hline Support from family, community, or religion & $\square$ & $\square$ & $\square$ & $\square$ & $\square$ \\
\hline Gender-segregation & $\square$ & $\square$ & $\square$ & $\square$ & $\square$ \\
\hline
\end{tabular}

70. We'd also like to talk about post-training factors that would be most important to you before deciding to pursue training. Is/are the a major factor, minor factor, or not a factor?

\begin{tabular}{|l|c|c|c|c|c|}
\hline & $\begin{array}{c}\text { Major factor } \\
\mathbf{1}\end{array}$ & $\begin{array}{c}\text { Minor factor } \\
\mathbf{2}\end{array}$ & $\begin{array}{c}\text { Not a factor } \\
\mathbf{3}\end{array}$ & $\begin{array}{c}\text { DON'T KNOW } \\
-\mathbf{8}\end{array}$ & $\begin{array}{c}\text { REFUSED } \\
-\mathbf{9}\end{array}$ \\
\hline Possibility of employment post-training & $\square$ & $\square$ & $\square$ & $\square$ & $\square$ \\
\hline Possibility of starting a business & $\square$ & $\square$ & $\square$ & $\square$ & $\square$ \\
\hline Additional skills & $\square$ & $\square$ & $\square$ & $\square$ & $\square$ \\
\hline Increase current income & $\square$ & $\square$ & $\square$ & $\square$ & $\square$ \\
\hline
\end{tabular}

71. Would you be willing to pay for further training or skills development programs?

1 YES

$2 \mathrm{NO}$
-8 DON'T KNOW

-9 REFUSED

72. Which month(s) are most convenient for training?
1 January
2 February
3 March
4 April
5 May

6 June

7 July

8 August

9 September

10 October
11 November

12 December

-8 DON'T KNOW

-9 REFUSED 


\section{SECTION I: FINANCE}

Now l'd like to talk to you about borrowing and saving money.

73. Have you borrowed money while in [FILL FROM Q3]?
1 YES
-8 DON'T KNOW
$2 \mathrm{NO}$
-9 REFUSED

[if 1, go to 74 . If $2,-8$, or -9 , go to 76 ]

74. Who did you borrow the money from when you needed it? READ RESPONSE OPTIONS
1 Friend
5 Mobile banking
2 Employer
6 Other (specify)
3 Relative
-8 DON'T KNOW
4 Bank
-9 REFUSED

75. What was the main purpose for the money you borrowed?
1 Income generating activities
5 Other (specify)
2 Living expenses
-8 DON'T KNOW
3 Training
-9 REFUSED
4 Family

[All who complete Q75, go to Q76]

76. If you had to borrow money to cover 1 month of rent, would you be able to?
1 YES
-8 DON'T KNOW
$2 \mathrm{NO}$
-9 REFUSED

77. Are you a part of a table banking group?
1 YES
-8 DON'T KNOW
2 NO
-9 REFUSED

78. Do you save a part of your earnings?
1 YES
-8 DON'T KNOW
$2 \mathrm{NO}$
-9 REFUSED

[If 1 , go to 79 . If $2,-8$, or -9 , go to $Q 82$ ] 
79. How do you save your earnings?

1 Banking institution

2 Table banking

3 Mobile banking

4 Village savings and loan association

5 Savings and credit cooperative organization
6 Personally

7 Other (specify)

-8 DON'T KNOW

-9 REFUSED

80. People have different reasons for saving, even though they may not save every month. What is your most important reason for saving?

1 To return home

2 To migrate to a different place

3 To start a business in [FILL FROM Q3]

4 For education or training

5 For marriage
6 To send money home

7 Other (specify)

-8 DON'T KNOW

-9 REFUSED

81. What is your second most important reason for saving?

1 To return home

2 To migrate to a different place

3 To start a business in [FILL FROM Q3]

4 For education or training

5 For marriage
6 To send money home

7 Other (specify)

-8 DON'T KNOW

-9 REFUSED

82. Do you send any money back to [FILL FROM Q5_1]?
1 YES
-8 DON'T KNOW
$2 \mathrm{NO}$
-9 REFUSED

83. Do you provide any in-kind support for your family members in [FILL FROM Q5_1] in other ways such as paying directly for school fees or bringing back items from the city?
1 YES
-8 DON'T KNOW
$2 \mathrm{NO}$
-9 REFUSED 
83. Since migrating, have you provided any of the following types of assistance to others who have migrated from [FILL FROM Q5_1]?

\begin{tabular}{|l|c|c|c|c|}
\hline & YES & NO & DON'T KNOW & REFUSED \\
$-\mathbf{8}$ & $\mathbf{2}$ & $\square$ & $\square$ \\
\hline Advice & $\square$ & $\square$ & $\square$ & $\square$ \\
\hline Housing & $\square$ & $\square$ & $\square$ & $\square$ \\
\hline Financial assistance & $\square$ & $\square$ & $\square$ & $\square$ \\
\hline Connections & $\square$ & $\square$ & $\square$ & $\square$ \\
\hline
\end{tabular}




\section{SECTION J: CLOSING}

READ TO RESPONDENT: That is the end of the survey questions. Thank you very much for your time.

\section{[GIVE RESPONDENT INCENTIVE. END INTERVIEW]}

Time End:

\section{Job List}

\begin{tabular}{|c|c|c|c|c|c|c|c|}
\hline 1 & Accounting clerk & 32 & Fish trading & 63 & Pet breeder & 94 & Technician \\
\hline 2 & Administrator & 33 & Fishing & 64 & Petrol seller & 95 & Thatching grass \\
\hline 3 & Agricultural trading & 34 & Forester & 65 & Petty trader & 96 & Timber trading \\
\hline 4 & Banker & 35 & General farm worker & 66 & Photography & 97 & Tour guide \\
\hline 5 & Bar operator & 36 & Hair dresser / barber & 67 & Pit latrine digger & 98 & Tout/turnboys \\
\hline 6 & Battery charging & 37 & Hawker & 68 & Planting & 99 & Traditional doctor \\
\hline 7 & $\begin{array}{l}\text { Bicycle (repair/ } \\
\text { transporter) }\end{array}$ & 38 & Hiring out a bull & 69 & Ploughing & 100 & Transporter (goods) \\
\hline 8 & Boat making & 39 & Hotel & 70 & Plumber & 101 & Tree seller, commercial \\
\hline 9 & Brokerage & 40 & House help & 71 & Policeman/woman & 102 & Unemployed \\
\hline 10 & Butcher & 41 & Income from another farm & 72 & Posho miller & 103 & Veterinary doctor \\
\hline 11 & Cane cutter & 42 & Industrial worker & 73 & Postmaster & 104 & Video business \\
\hline 12 & Caretaker/groundsman & 43 & Jaggery & 74 & Rental of properties & 105 & Waiter/cook \\
\hline 13 & Carpenter & 44 & Lab attendant & 75 & Research & 106 & Watchman \\
\hline 14 & Casual worker & 45 & Laundry business & 76 & $\begin{array}{l}\text { Retail shop/kiosk/ } \\
\text { shopkeeping }\end{array}$ & 107 & Weaving \\
\hline 15 & Charcoal burning & 46 & Livestock trader & 77 & Road constructor & 108 & $\begin{array}{l}\text { Welding/painting/ } \\
\text { blacksmith }\end{array}$ \\
\hline 16 & Chief & 47 & Local brewing & 78 & Sales person & 109 & Wine tapper \\
\hline 17 & Civil leader & 48 & Lumbering/wood cutting & 79 & Sand harvesting & & \\
\hline 18 & Cleaner & 49 & Making pots & 80 & School business & & \\
\hline 19 & $\begin{array}{l}\text { Clothes/shoes business } \\
\text { (trading) }\end{array}$ & 50 & Manager & 81 & Secretary & & \\
\hline 20 & Cobbler & 51 & Masonry & 82 & $\begin{array}{l}\text { Selling mandasi cakes/ } \\
\text { bread/cook }\end{array}$ & & \\
\hline 21 & Committee member & 52 & Matatu business & 83 & Selling water & & \\
\hline 22 & Cook/caterer & 53 & Mechanic & 84 & Sheep shearer & & \\
\hline 23 & Craftsman/artisan & 54 & Medical health business & 85 & Soldier & & \\
\hline 24 & Curio trader & 55 & Messenger & 86 & Sports/coach & & \\
\hline 25 & $\begin{array}{l}\text { Dealing ropes/sisal/ } \\
\text { firewood }\end{array}$ & 56 & Miller & 87 & Spraying & & \\
\hline 26 & Driver & 57 & Mining & 88 & Student & & \\
\hline 27 & Earning dividends & 58 & Non-agricultural business & 89 & Subordinate civil services & & \\
\hline 28 & Electrician & 59 & Nurse & 90 & Surveyor & & \\
\hline 29 & Equipment operator & 60 & Other, specify & 91 & Tailor & & \\
\hline 30 & Extension agent & 61 & Pastor/religious services & 92 & Tea picker & & \\
\hline 31 & Farm worker & 62 & Pension & 93 & Teacher & & \\
\hline
\end{tabular}




\section{SECTION K: GUIDELINES FOR REQUESTING THAT THE RESPONDENT RECRUIT ADDITIONAL RESPONDENTS}

We would like your help in finding three other people you know to participate in this survey. We are looking for (1) migrants aged 18-35 who were born in (2) villages in Garissa or Bungoma counties (3) that currently live in Nairobi, Garissa town, or Bungoma town.

The interview will take them between 30-45 minutes. They will receive an incentive (like you) if they participate. Also, you will receive mobile phone airtime for each person you recruit. You'll get 75 shillings for the first person, 75 shillings for the second, and 100 shillings for the third.

I'll give you three invitations that you can pass along to potential recruits. The recruits can then contact Research Solutions Africa to schedule an interview. It is important that the recruits have the invitation (or the unique ID code) when they schedule an interview.

Other points about who to invite:

- You should only recruit people that you know personally or through a business relationship. Do not recruit strangers.

- You can only recruit three people, so make sure you only give the invitation to someone that you think will truly complete an interview.

It is really important that you recruit additional people. This survey will help understand the opportunities and challenges for youth migrants. The results of the survey will improve program interventions for pastoral and agricultural youth.

Do you have any questions?

Are you willing to recruit additional respondents?

$\square$ YES $\rightarrow \quad$ WRITE INVITATION IDS ON THE THREE INVITATIONS.

GIVE TO RESPONDENT.

TELL RESPONDENT YOU WILL FOLLOW UP.

$\square$ NO $\rightarrow \quad$ ANSWER QUESTIONS.

ASK "WHAT ARE YOU CONCERNED ABOUT?"

ENCOURAGE RESPONDENT. REASSURE ABOUT CONFIDENTIALITY.

IF STILL REFUSES, GIVE INVITATIONS ANYWAY; END INTERVIEW. 
RTI International is an independent, nonprofit research institute dedicated to improving the human condition. We combine scientific rigor and technical expertise in social and laboratory sciences, engineering, and international development to deliver solutions to the critical needs of clients worldwide. 